\begin{tabular}{cc}
\hline JPPIPA, Vol.2 No.1 2017 \\
Jurnal Penelitian Pendidikan IPA \\
\hline$U_{N E S A}$
\end{tabular}

\title{
BUKU AJAR INTERACTIVE BOOK UNTUK MENINGKATKAN KEMAMPUAN BERPIKIR KREATIF SISWA SEKOLAH DASAR
}

Oleh:

Fauziah Rachmawati ${ }^{1}$, Tjandra Kirana ${ }^{2}$, Wahono Widodo ${ }^{3}$

${ }^{1}$ Prodi Pendidikan Dasar, Pascasarjana, Universitas Negeri Surabaya 60231, Indonesia

${ }^{2}$ Prodi Pendidikan Sains, Pascasarjana, Universitas Negeri Surabaya 60231, Indonesia

${ }^{3} J u r u s a n$ IPA, Fakultas MIPA, Universitas Negeri Surabaya, Surabaya 60231, Indonesia.

\begin{abstract}
Abstrak
Penelitian ini bertujuan untuk menghasilkan Interactive Book yang valid, praktis, dan efektif untuk melatihkan keterampilan berpikir kreatif siswa. Penelitian ini dilaksanakan dengan menggunakan model 4-D (Four-D Model), yaitu tahap pendefinisian (define), perancangan (design), pengembangan (develop) dan diujicobakan di kelas V SD Islam As-Salam Kota Malang tahun ajaran 2016/2017 dengan Pretest-Posttest Design. Pengumpulan data menggunakan metode observasi, tes, dan angket. Teknik analisis data menggunakan analisis deskriptif kuantitatif dan kualitatif. Hasil penelitian ini menunjukkan: 1) Interactive Book yang dikembangkan berkategori sangat valid; 2) Pembelajaran menggunakan Interactive Book ditinjau dari keterlaksanaan RPP berkategori sangat valid dan aktivitas siswa sesuai dengan tahap-tahap pada model guided discovery learning; dan 3) Keefektivan Interactive Book dalam pembelajaran ditinjau dari ketuntasan adalah mengalami kenaikan dari rata-rata 65 menjadi 84 dengan N-Gain 0,53 (sedang). Berdasarkan hasil analisis data, dapat disimpulkan bahwa Interactive Book dan perangkat pembelajaran menggunakan telah valid, praktis, dan efektif untuk meningkatkan keterampilan berpikir kreatif.
\end{abstract}

Kata Kunci : pengembangan buku ajar, interactive book, keterampilan berpikir kreatif.

\section{Abstract}

This study aims to produce a valid Interactive Book, practical, and effective for improving creative thinking skills of students. This research was conducted using three stages of 4-D model (Four-D Model), which is the stage of definition (define), design (design), development (develop) and tested in class V SD Islam As-Salam Malang academic year 2016 / 2017 with a pretestposttest design. Collecting data using observation, testing, and questionnaires. Data were analyzed using descriptive analysis of quantitative and qualitative. The results showed: 1) Interactive Book developed very valid category; 2) using the Interactive Learning Book category in terms of enforceability RPP very valid and student activity in accordance with the stages of the model of guided discovery learning; and 3) The effectiveness of Interactive Book of learning in terms of completeness is an increase from an average of 65 to 84 with $\mathrm{N}$-Gain 0.53 (moderate). Based on the analysis, it can be concluded that the Interactive Book and learning to use the device has a valid, practical, and effective way to improve the skills of creative thinking.

Keywords: textbook development, interactive book, creative thinking skills.

C 2017 Universitas Negeri Surabaya

\section{${ }^{1}$ Alamat Korespondensi:}

Prodi Pendidikan Dasar, Pascasarjana,

p-ISSN: 2527-7537

Universitas Negeri Surabaya 60231, Indonesia

e-ISSN: 2549-2209

Email: arifinmuhammadyusuf@gmail.com 


\section{PENDAHULUAN}

Persaingan dunia kerja yang ketat pada abad 21 dan semakin canggihnya teknologi yang tersedia, mengharuskan manusia terus berpikir kreatif menghasilkan ide-ide dan terobosan baru menghadapai permasalahan yang berguna mewujudkan perdamaian. Hal ini sesuai pendapat Olsen (2013) yang mengatakan ketrampilan yang dibutuhkan di abad 21 adalah kreativitas, inovasi, pemecahan masalah, dan keterampilan teknologi serta pertumbuhan ekonomi secara nasional.

Berdasarkan Permendiknas No. 2 Tahun 2008 mengenai buku teks, pada pasal 1 dijelaskan bahwa buku adalah acuan wajib untuk digunakan di satuan pendidikan dasar dan menengah atau perguruan tinggi yang memuat materi pembelajaran dalam rangka peningkatan keimanan, ketakwaan, akhlak mulia, dan kepribadian, penguasaan ilmu pengetahuan dan teknologi, peningkatan kepekaan dan kemampuan estetis, peningkatan kemampuan kinestetis dan kesehatan yang disusun berdasarkan Standar Nasional Pendidikan. Buku ajar disusun secara sistematis dan menarik mencakup tentang: isi materi, metode, dan evaluasi yang dapat digunakan secara mandiri.

Keterampilan berpikir kreatif merupakan salah satu keterampilan berpikir yang menciptakan suatu ide atau gagasan yang baru. Hal ini didukung oleh pernyataan Sudarma (2013:17) yang menyatakan bahwa keterampilan berpikir kreatif adalah kemampuan melahirkan ide atau gagasan baru atau gagasan kreatif mengenai sesuatu hal. Berpikir kreatif berarti memandang sesuatu dari berbagai macam sudut pandang yang berbeda dengan berbagai kemungkinan yang ada. Dalam pembelajaran di dalam kelas, keterampilan berpikir kreatif juga memiliki pengaruh positif. Penelitian yang dilakukan di Jakarta menunjukan bahwa keterampilan berpikir kreatif memiliki pengaruh positif terhadap prestasi belajar (Supardi, 2014). Keterampilan ini bahkan menjadi salah satu tujuan pendidikan nasional yang tertuang dalam UU No. 20 Tahun 2003 yaitu bertujuan untuk mengembangkan potensi peserta didik agar menjadi manusia yang beriman dan bertakwa kepada Tuhan Yang Maha Esa, berakhlak mulia, sehat, berilmu, cakap, kreatif, dan mandiri.

Pembelajaran IPA juga mengembangkan kemampuan berpikir kreatif dan rasa ingin tahu melalui penemuan berdasarkan pengalaman langsung. Melalui kerja ilmiah siswa dilatih untuk memanfaatkan fakta, membangun konsep, prinsip, teori sebagai dasar untuk berfikir kreatif, kritis, analitis dan divergen.

Menindaklanjuti hal tersebut, pemerintah gencar melakukan pengadaan buku ajar yang relevan digunakan di sekolah seperti buku tematik yang terpusat dari Kemendikbud. Hal ini dikarenakan buku merupakan sesuatu yang tidak bisa dipisahkan dalam siklus pembelajaran. Ini tidak beda halnya dengan anak Sekolah Dasar yang masih dalam tahap perkembangan konkret yaitu harus menggunakan media pembelajaran yang menarik, baik dari tampilan, maupun dari isi. Maka dari itu harus menggunakan buku ajar semenarik mungkin.

Dari hasil observasi di beberapa sekolah, ditemukan bahwa hasil belajar IPA siswa cenderung menurun. Beberapa faktor yang paling berperan dalam masalah ini adalah buku sumber yang digunakan. Berdasarkan jurnal yang ditulis oleh Marguerite dan Gerry (1988) salah satu solusi untuk mengatasi hal ini adalah melalui interactive book. Metode yang digunakan adalah dengan membuat buku interaktif yang berisikan kegiatan didalam ruang dan dari dukungan para karakter yang membantu menarik perhatian anakserta bisa meningkatkan kreatifitas anak.

Terdapat delapan jenis buku interaktif yaitu pop-up, flip the flap, pull tab, hidden object book, games, participation, play-A-Song, touch and feel. Dalam perancangan, penulis membuat buku dengan menggunakan teknik lift the flap (flip the flap), pop up, dan lembar bermagnet.

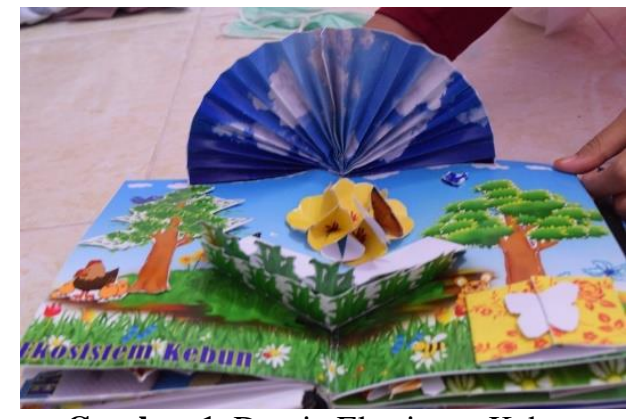

Gambar 1. Desain Ekosistem Kebun dalam Buku Interactive Book

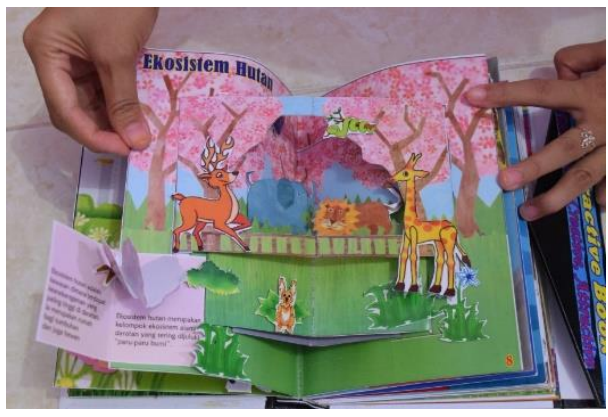

Gambar 2. Desain Ekosistem Hutan dalam Buku Interactive Book

Selain itu penting untuk membangun komunikasi antara guru dan siswa dalam proses belajar mengajar menjadi salah satu bagian penting pada keberlangsungan proses belajar mengajar. Selain komunikasi antara guru dan siswa, 
pemilihan mediayang tepat menjadi salah satu faktor penting agar transfer ilmu pengetahuan dari guru dapat lebih maksimal sehingga siswa tidak hanya mendengar apa yang disampaikan oleh guru tetapi juga mengikuti proses pembelajaran dengan benar. Dalam pembelajaran dibutuhkan suatu media untuk memperlancar proses pembelajaran. Salah satu solusi dalam mengatasi hal tersebut adalah buku ajar interaktif.

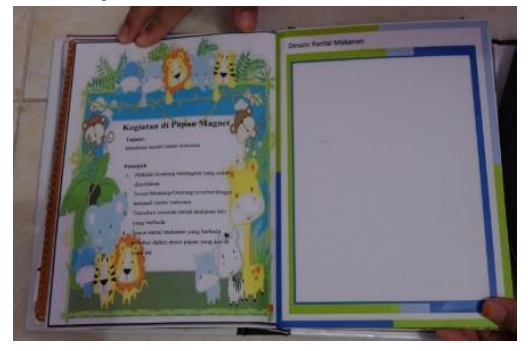

Gambar 3. Desain Lembar Magnet pada Buku Interactive Book

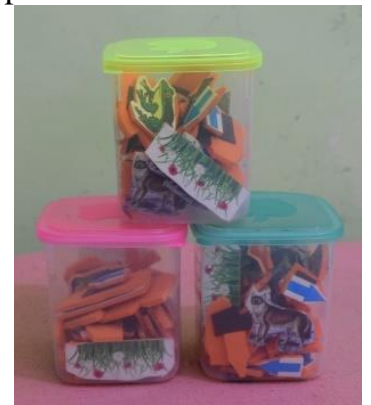

Gambar 4. Desain pion untuk dipasang di Lembar Magnet pada Buku Interactive Book

Menurut UU Lingkungan Hidup No.23 th 1997 , ekosistem adalah tatanan secara utuh menyeluruh antara segenap unsur lingkungan hidup yang saling mempengaruhi. Jadi ekosistem adalah tatanan unsur lingkungan hidup yang merupakan kesatuan utuh menyeluruh dan saling mempengaruhi dalam membentuk keseimbangan, stabilitas, dan produktivitas lingkungan hidup. Berdasarkan hasil observasi ditemukan bahwa guru belum melakukan pengembangan buku ajar materi ekosistem yang didesain agar siswa memiliki kemampuan bernalar IPA yang baik dan untuk meningkatkan kreatifitas siswa. Sehingga perlu dilakukan pengembangan buku ajar yang harapannya dapat meningkatkan kreatifitas siswa.

Siswa diharapkan terlibat aktif dalam pembelajaran IPA dan guru hanya sebagai fasilitator dan motivator untuk meyakinkan siswa agar mampu memberikan argumen dan memecahkan masalah bersama teman sejawatnya. Berdasarkan uraian di atas maka akan dilakukan pengembanganbuku ajar yang melibatkan siswa ini berjudul "Pengembangan Buku Ajar Interactve
Book untuk Meningkatkan Kemampuan Berpikir Kreatif Siswa Sekolah Dasar".

Berdasarkan latar belakang di atas, yang menjadi rumusan masalah dalam penelitian ini adalah sebagai berikut: (1) Bagaimana validitas buku ajar interactive book untuk meningkatkan kemampuan berpikir kreatif siswa?, (2) Bagaimana kepraktisan buku ajar interactive book untuk meningkatkan kemampuan berpikir kreatif siswa?, (a) Bagaimana keterlaksanaan Rencana Pelaksanaan Pembelajaran (RPP) dengan menggunakan interactive book?, (b) Bagaimana aktivitas siswa selama pelaksanaan pembelajaran menggunakan interactive book?, (3) Bagaimana keefektifan buku ajar interactive book untuk meningkatkan kemampuan berpikir kreatif siswa?, (a) Bagaimana respon siswa setelah diterapkan proses pembelajaran dengan menggunakan buku ajar interactive book?, (b) Bagaimana tingkat kemampuan kreatif siswa setelah diterapkan proses pembelajaran dengan menggunakan buku ajarinteractive book?, (c) Bagaimana hasil belajar siswa setelah menggunakan buku ajar interactive book?

\section{METODE}

Penelitian ini adalah penelitian pengembangan dengan menggunakan 4D model, yaitu mengembangkan bahan ajar interactive book untuk siswa kelas VA SD dengan materi ekosistem.

Sasaran penelitian adalah bahan ajar interactive book untuk melatihkan keterampilan berpikir kreatif pada materi ekosistem yang akan diujikan pada 25 siswa kelas V. Namun karena 3 siswa mengikuti lomba dan 2 siswa sakit maka yang mengikuti pembelajaran dari awal sampai akhir ada 20 siswa.

Penelitian ini menggunakan rancangan penelitian pengembangan milik Thiagarajan, Semmel, and Semmel (1974:5) yang disebut 4-D (four $D$ model). Model Four-D terdiri dari 4 tahapan yaitu: (1) penetapan (Define); (2) perancangan (Design); (3) pengembangan (Develop); (4) penyebaran (Disseminate). Adapun rancangan pengembangan 4-D pada penelitian ini dapat diabstraksikan dalam bagan berikut.

\section{Tahap Pendefinisian (Define)}

Tahap pendefinisan merupakan tahapan awal dalam pengembangan 4D yang bertujuan untuk menetapkan kebutuhan-kebutuhan pembelajaran dengan menganalisis tujuan dan batasan materi pokok yang akan dikembangkan. The purpose of this stage (define) is to stimulate and define instructional requiments (Thiagarajan et la., 1974). Pada tahap ini meliputi 5 langkah pokok: analisis awal akhir (front-end analysis), analisis siswa (leaner analysis), analisis tugas (task analysis), analisis konsep (concept analysis), dan perumusan 
tujuan pembelajaran (specifying instructional objectives). Tahapan-tahapan tersebut diantaranya adalah Analisis Awal-Akhir (front-end analysis), dan Analisis Siswa. Analisis Tugas (Task Analysis)

\section{Tahap Perancangan (Design)}

Dalam tahap perancangan dilakukan setelah menetapkan tujuan pembelajaran yang dicapai siswa. The purpose of this stage is to design prototype instructional material (Thiagarajan et al., 1974). Dalam bukunya disebutkan pada tahap perancangan bertujuan untuk menyiapkan prototype buku ajar. Terdapat empat langkah pada tahap perancangan yakni: penyusunan tes acuan patokan (constructing criterion-referenced test), pemilihan media (media selection), pemilihan format buku ajar (format selection), membuat perancangan buku awal (initial design). Kegiatan penting dalam proses perancangan adalah pemilihan media yang digunakan dan format untuk bahan serta pembuatan perancangan awal.

\section{Tahap Pengembangan (Development)}

Tujuan tahap pengembangan adalah menghasilkan buku ajar yang sudah direvisi berdasarkan masukan dari para pakar. The purpose of stage is to modify the prototype instructional material (Thiagarajan, et al., 1974). Tahapan pada tahap pengembangan yakni: penilaian ahli (expert appraisal) dan uji coba pengembangan (development testing). Uji coba, revisi, dan uji coba kembali terus dilakukan hingga diperoleh produk yang konsisten dan efektif (Thiagarajan et al., 1974). Rancangan awal buku ajar yang telah disusun, menjadi langkah awal pelaksanaan tahap pengembangan.

Tahap pengembangan dalam penelitian meliputi: (a) validasi buku ajar dan perangkat oleh para pakar diikuti dengan revisi; (b) revisi berdasarkan hasil validasi; (c) uji coba terbatas dengan siswa sesungguhnya; (d) revisi berdasarkan pelaksanaan uji coba terbatas; (e) pelaksanaan uji coba lapangan. Beberapa tahap pengembangan diantaranya adalah validasi buku ajar dan perangkat, revisi berdasarkan hasil validasi, uji coba, revisi terhadap draft inetarctive book dan perangkat pembelajaran, uji coba lapangan

\section{Tahap Penyebaran (Disseminate)}

Tahap ini tidak dilakukan karena penelitian ini masih terbatas pada tahap perkembangan. Rancangan uji coba digunakan untuk mengujicobakan hasil pengembangan interactive book. Rancangan penelitian menggunakan rancangan pretest-posttest design. Rancangan penelitian ini melibatkan satu kelompok yang diobservasi pada tahap pretest $\left(O_{1}\right)$ yang kemudian dilanjutkan dengan perlakuan tertentu $(X)$ dan posttest $\left(\mathrm{O}_{2}\right)$ (Sugiyono, 2014). Rancangan pretestposttest design dapat ditulis dengan bentuk:

\section{$\mathrm{O}_{1} \mathbf{X} \mathbf{O}_{2}$}

Keterangan:

$\mathrm{O}_{1}=$ pretest (pengukuran hasil belajar dan keterampilan berpikir kreatif siswa sebelum perlakuan)

$\mathrm{O}_{2}=$ Posttest (pengukuran hasil belajar dan keterampilan berpikir kreatif sesudah perlakuan)

$\mathrm{X}=$ Perlakuan (pembelajaran menggunakan interactive book).

Teknik Pengumpulan Data dilakukan dengan observasi/pengamatan

Observasi dilakukan untuk mengumpulkan data penelitian mengenai aktivitas siswa dan keterlaksanaan RPP saat kegiatan pembelajaran berlangsung. Observasi dilakukan oleh dua orang pengamat menggunakan lembar pengamatan yang sama untuk mengetahui aktivitas siswa dan keterlaksanaan RPP. Mencatat data observasi bukanlah sekedar mencatat, tetapi juga mengadakan pertimbangan kemudian mengadakan penilaian ke dalam suatu skala bertingkat (Arikunto, 2010).

Adapun kegiatan siswa yang diamati selama kegiatan pembelajaran menurut Borich (1994) meliputi students acting on, thinking about, or otherwise using the content being taught. Seperti lembar observasi pada keterlaksanaan RPP, lembar pengamatan siswa berupa tabel yang berisi kolomkolom kegiatan yang diamati serta pilihan skor penilaian.

Observer satu dan dua mengamati di bagian belakang kelas dengan membawa lembar pengamatan masing-masing. Tiap observer tidak diperkenankan untuk mendiskusikan skor yang akan diberikan pada saat pengamatan. Observer juga diminta untuk tidak membuat banyak gerakan, misalnya berjalan mondar-mandir dan bersuara yang membuat konsentrasi belajar siswa menurun. Pengisian lembar observasi dilaksanakan saat pelaksanaan pembelajaran, dan dilaksanakan bersamaan antara lembar pengamatan keterlaksanaan pembelajaran dan aktivitas siswa dengan pemberian tes dan pemberian angket.

Widoyoko (2015) kuisioner/angket merupakan metode pertanyaan atau pernyataan tertulis kepada responden untuk diberikan respon sesuai dengan permintaan pengguna. Dalam penelitian ini kuisioner/angket digunakan untuk memperoleh data tentang tanggapan dan saran perbaikan dari validator (materi, penyajian, bahasa, dan kegrafikan), guru dan siswa. Teknik pengumpulan data berupa angket ini juga digunakan untuk menilai kelayakan buku ajar interaktif yang dikembangkan meliputi kelayakan materi/isi, penyajian, kebahasaan dan kegrafikan, serta respon siswa dan guru terhadap pembelajaran dengan menggunakan Interactive Book. 
Metode analisis data merupakan cara yang digunakan untuk mengolah data yang berhubungan dengan rumusan masalah. Setelah semua data terkumpul, maka langkah selanjutnya adalah menganalisis data sehingga mendapatkan suatu kesimpulan. Data yang terkumpul diklasifikasikan menjadi data kuantitatif dan data kualitatif. Analisis datanya peneliti menggunakan teknik analisis data kuantitatif dan kualitatif.

\section{HASIL DAN PEMBAHASAN}

Pada bagian ini akan dijabarkan hasil pengembangan Interactive Book untuk meningkatkan keterampilan berpikir kreatif siswa Kelas V dan uji coba buku ajar dan perangkat di kelas. Subjek pengembangan dalam penelitian ini adalah buku ajar. Subjek pada pembelajaran menggunakan Interactive Book sebanyak 25 siswa kelas V SD Islam As-Salam Kota Malang. Namun karena ada dua siswa sakit dan tiga siswa ikut lomba, jadi penelitian terdiri dari 20 siswa. Setelah Interactive Book dikembangkan, dilakukan validasi dan diuji coba untuk menghasilkan produk yang layak.
Penelitian ini merupakan penelitian pengembangan Research and Development $(R \& D)$. Prosedur penelitian mengadopsi model 3-D (define, design, develop) dari model pengembangan yang dikembangkan oleh Thiagarajan, dkk (1974). Dalam penelitian ini, peneliti hanya melaksanakan tiga tahap yaitu sampai tahap pengembangan sehingga model pengembangan yang digunakan disederhanakan menjadi model 3-D (define, design, develop).

Validitas adalah pernyataan valid atau tidak valid dari ahli setelah menelaah buku ajar dan hasil perangkat pembelajaran yang dikembangkan dengan menggunakan panduan lembar validasi yang telah disusun. Validasi perangkat meliputi buku ajar, silabus, RPP, evaluasi, dan pretest dan prostest. Interactive Book merupakan buku pegangan yang digunakan siswa dalam pembelajaran. Buku ajar yang telah didesain oleh peneliti kemudian divalidasi oleh validator dengan hasil penilaian dapat dilihat secara ringkas pada Tabel 1.

Tabel 1. Hasil Penilaian Validitas Interactive Book

\begin{tabular}{|c|c|c|c|c|c|}
\hline \multirow{2}{*}{ No } & \multirow{2}{*}{ Kriteria Penilaian } & \multicolumn{2}{|c|}{ Penilaian } & \multirow{2}{*}{ Rerata } & \multirow{2}{*}{ Kategori } \\
\hline & & V1 & V2 & & \\
\hline 1 & Kelayakan Isi & 3,62 & 3,75 & 3,69 & Sangat Valid \\
\hline 2 & Kelayakan Penyajian & 3,78 & 3,78 & 3,78 & Sangat Valid \\
\hline 3 & Kelayakan Bahasa & 3 & 3 & 3,00 & Valid \\
\hline 4 & Aspek Penilaian Kreativitas & 4 & 4 & 4,00 & Sangat Valid \\
\hline \multirow[t]{4}{*}{5} & Aspek Kelayakan Kegrafikan & 3,33 & 3,33 & 3,33 & Valid \\
\hline & Total & 17,73 & 17,86 & - & Sangat Valid \\
\hline & Reliabilitas Instrumen & & 0,99 & & \multirow{2}{*}{ Sangat Reliabel } \\
\hline & Prosentase Reliabilitas & & $99 \%$ & & \\
\hline
\end{tabular}

Keterangan

V1: Validator 1, V2 : Validator 2

Berdasarkan Tabel 1, hasil penilaian validitas oleh validator terhadap Interactive Book didesain adalah 3,56 yang berarti sangat baik dan dengan reliabel $99 \%$ yang berarti sangat reliabel. Maka buku ajar yang dikembangkan peneliti selanjutnya dapat digunakan pada ujicoba I.

\section{Hasil Validasi Tes Berpikir Kreatif}

Tes hasil belajar meliputi dan tes keterampilan berpikir kreatif. Tes keterampilan berpikir kreatif dinilai oleh validator dan disajikan pada Tabel 2.

Tabel 2. Hasil Validasi Keterampilan Berpikir Kreatif

\begin{tabular}{|c|c|c|c|c|c|c|c|c|}
\hline \multirow[t]{2}{*}{ No Soal } & \multicolumn{2}{|c|}{$\begin{array}{l}\text { Penilaian } \\
\text { Validitas Isi } \\
\text { Validator }\end{array}$} & \multirow[t]{2}{*}{$\begin{array}{c}\text { Rata- } \\
\text { rata }\end{array}$} & \multirow[t]{2}{*}{ Ket } & \multicolumn{2}{|c|}{$\begin{array}{c}\text { Penilaian Validitas } \\
\text { Bahasa dan } \\
\text { Penulisan Soal } \\
\text { Validator }\end{array}$} & \multirow[t]{2}{*}{$\begin{array}{l}\text { Rata- } \\
\text { rata }\end{array}$} & \multirow[t]{2}{*}{ Ket } \\
\hline & 1 & 2 & & & 1 & 2 & & \\
\hline 1 & 3 & 4 & 3,5 & Sangat Valid & 4 & 4 & 4 & Sangat Valid \\
\hline 2 & 3 & 4 & 3,5 & Sangat Valid & 4 & 4 & 4 & Sangat Valid \\
\hline 3 & 3 & 4 & 3,5 & Sangat Valid & 4 & 4 & 4 & Sangat Valid \\
\hline 4 & 3 & 4 & 3,5 & Sangat Valid & 4 & 4 & 4 & Sangat Valid \\
\hline Total & 12 & 16 & 3,5 & Sangat Valid & 16 & 16 & 4 & Sangat Valid \\
\hline \multicolumn{3}{|c|}{ Reliabilitas } & $86 \%$ & Sangat Valid & & $100 \%$ & & Sangat Valid \\
\hline
\end{tabular}


Kepraktisan buku ajar dan perangkat pembelajaran dapat dilihat dari dua aspek yaitu keterlaksanaan pembelajaran dan aktivitas siswa. Keterlaksanaan pembelalajaran dan aktivitas siswa dapat dinilai melalui penelitian yang dilakukan terhadap 20 siswa kelas V SD Islam As-Salam Malang dan diamati oleh dua orang pengamat.

\section{Keterlaksanaan Rencana Pelaksanaan Pembelajaran (RPP)}

Pembelajaran dilaksanakan selama tiga kali pertemuan dengan alokasi waktu tiap pertemuan selama 4 x 35 menit. Pembelajaran dilaksanakan di gazebo dan diamati oleh dua orang pengamat. Adapun hasil penilaian pengamatan terhadap keterlaksanaan pembelajaran disajikan pada Tabel 3.

Tabel 3. Keterlaksanaan RPP

\begin{tabular}{|c|c|c|c|c|c|c|c|}
\hline \multirow{2}{*}{ No } & \multirow{2}{*}{ Aspek yang diamati } & \multicolumn{2}{|c|}{ RPP 1} & \multicolumn{2}{|c|}{ RPP 2} & \multicolumn{2}{|c|}{ RPP 3} \\
\hline & & P1 & $\mathbf{P 2}$ & $\mathbf{P 1}$ & $\mathbf{P 2}$ & P1 & $\mathbf{P 2}$ \\
\hline 1 & Pendahuluan & 3 & 4 & 4 & 3,3 & 3,7 & 3,7 \\
\hline 2 & $\begin{array}{l}\text { Kegiatan untuk meningkatkan keterampilan berpikir asli } \\
\text { siswa }\end{array}$ & 4 & 4 & 4 & 3 & 4 & 4 \\
\hline 3 & $\begin{array}{l}\text { Kegiatan untuk meningkatkan keterampilan berpikir luwes } \\
\text { siswa }\end{array}$ & 4 & 4 & 4 & 4 & 4 & 4 \\
\hline 4 & $\begin{array}{l}\text { Kegiatan untuk meningkatkan keterampilan berpikir rinci } \\
\text { siswa }\end{array}$ & 4 & 4 & 4 & 4 & 3 & 3 \\
\hline 5 & $\begin{array}{l}\text { Kegiatan untuk meningkatkan keterampilan berpikir lancar } \\
\text { siswa }\end{array}$ & 4 & 4 & 4 & 4 & 4 & 4 \\
\hline 6 & Penggunaan Interactive Book & 4 & 4 & 4 & 4 & 3,5 & 4 \\
\hline 7 & Penutup & 4 & 4 & 4 & 4 & 3,5 & 4 \\
\hline 8. & Suasana Kelas & 4 & 4 & 4 & 4 & 4 & 4 \\
\hline & Total & 31,3 & 32 & 32 & 30,3 & 29,7 & 30,7 \\
\hline & Keterlaksanaan & \multicolumn{2}{|c|}{$100 \%$} & \multicolumn{2}{|c|}{$100 \%$} & \multicolumn{2}{|c|}{$100 \%$} \\
\hline & Reliabilitas Instrumen & \multicolumn{2}{|c|}{0,99} & \multicolumn{2}{|c|}{0,97} & \multicolumn{2}{|c|}{0,98} \\
\hline & Prosentase Reliabilitas & \multicolumn{2}{|c|}{$98 \%$} & \multicolumn{2}{|c|}{$97 \%$} & \multicolumn{2}{|c|}{$98 \%$} \\
\hline
\end{tabular}

Tabel 4 menggambarkan keterlaksanaan RPP pada penelitian di kelas. Pendahuluan pertemuan 1, 2, dan 3 memiliki skor yang sama. Pada aspek berpikir asli, skor tertinggi tampak pada pertemuan pertama dan ketiga. Aspek berpikir luwes skor tertinggi pada semua pertemuan. Aspek berpikir rinci pada pertemuan 1 dan 2 memiliki skor yang tinggi. Pada aspek berpikir lancar skor tertinggi tampak pada pertemuan pertemuan satu, dua, dan tiga. Pada bagian penggunaan Interactive Book skor tertinggi pada pertemuan 1 dan 2. Kegiatan penutup, skor tertinggi pada pertemuan pertama dan kedua. Suasana kelas tampak kondusif pada semua pertemuan.

Tabel 4. Keterlaksanaan Kegiatan Untuk Meningkatkan Keterampilan Kreatif

\begin{tabular}{cccccccc}
\hline \multirow{2}{*}{ No } & \multirow{2}{*}{ Aspek yang diamati } & \multicolumn{2}{c}{ RPP 1 } & \multicolumn{2}{c}{ RPP 2 } & \multicolumn{2}{c}{ RPP 3 } \\
\cline { 3 - 7 } & P1 & P2 & P1 & P2 & P1 & P2 \\
\hline 1 & Berpikir Asli & 4 & 4 & 4 & 3 & 4 & 4 \\
\hline 2 & Berpikir Luwes & 4 & 4 & 4 & 4 & 4 & 4 \\
\hline 3 & Berpikir Rinci & 4 & 4 & 4 & 4 & 3 & 3 \\
\hline 4 & Berpikir Lancar & 4 & 4 & 4 & 4 & 4 & 4 \\
\hline & Total & 16 & 16 & 16 & 15 & 16 & 15 \\
\hline & Keterlaksanaan & \multicolumn{2}{c}{$100 \%$} & $100 \%$ & $100 \%$ \\
\hline & Reliabilitas Instrumen & \multicolumn{2}{c}{1} & & 0,97 & 0,97 \\
\hline
\end{tabular}

\section{Aktivitas Siswa}

Aktivitas siswa diamati oleh dua orang pengamat pada penelitian. Pengamatan dilakukan selama 3 kali pertemuan yang merupakan implementasi dari RPP. Secara ringkas aktivitas siswa selama pembelajaran pada penelitian dapat dilihat pada Gambar 1.

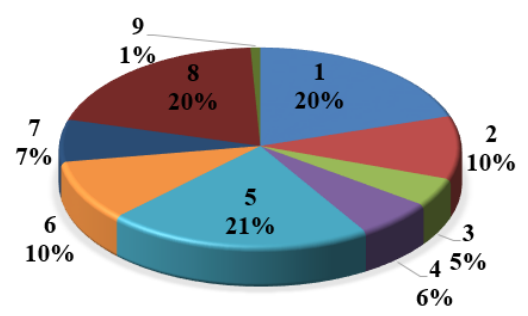

Gambar 1. Persentase Aktivitas Siswa Pertemuan 1 
Keterangan:

1. Memperhatikan guru saat memberikan arahan dan informasi

2. Membaca informasi atau bacaan yang terdapat dalam di Interactive Book

3. Menyampaikan pendapat atau jawaban dari pertanyaan yang diajukan oleh guru

4. Mengajukan pertanyaan

5. Melakukan pengamatan, percobaan, atau bekerja

6. Mendiskusikan suatu masalah

7. Mencatat segala informasi yang didapatkan dari proses pembelajaran

8. Mengerjakan LKS yang ada di di Interactive Book

9. Perilaku yang tidak relevan

Gambar 1 merupakan persentase dari aktivitas siswa pada proses pembelajaran pertemuan pertama. Terdapat delapan aktivitas siswa yang diamati selama kegiatan pembelajaran berlangsung.

Gambar 1 tersebut menunjukkan kegiatan memperhatikan guru saat memberikan arahan dan informasi sebanyak $20 \%$, membaca informasi atau bacaan yang terdapat dalam di Interactive Book $10 \%$, menyampaikan pendapat atau jawaban dari pertanyaan yang diajukan oleh guru 5\%, mengajukan pertanyaan sebanyak $6 \%$, melakukan pengamatan, percobaan, atau bekerja sebanyak $21 \%$, mendiskusikan suatu masalah $10 \%$, mencatat segala informasi yang didapatkan $7 \%$, mengerjakan LKS yang ada di di Interactive Book 20\%, dan perilaku yang tidak relevan sebanyak $1 \%$.

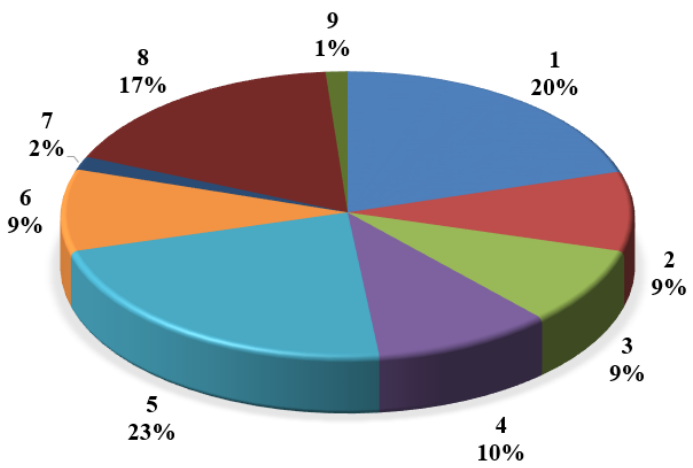

Gambar 2. Persentase Aktivitas Siswa Pertemuan 2

Keterangan:

1. Memperhatikan guru saat memberikan arahan dan informasi

2. Membaca informasi atau bacaan yang terdapat dalam di Interactive Book

3. Menyampaikan pendapat atau jawaban dari pertanyaan yang diajukan oleh guru

4. Mengajukan pertanyaan

5. Melakukan pengamatan, percobaan, atau bekerja
6. Mendiskusikan suatu masalah

7. Mencatat segala informasi yang didapatkan dari proses pembelajaran

8. Mengerjakan LKS yang ada di di Interactive Book

9. Perilaku yang tidak relevan

Gambar 2 merupakan persentase dari aktivitas siswa pada pembelajaran pertemuan kedua. Terdapat delapan aktivitas siswa yang diamati selama kegiatan pembelajaran berlangsung.

Gambar 2 di atas menunjukkan hasil kegiatan memperhatikan guru saat memberikan informasi sebanyak 20\%, membaca informasi atau bacaan yang terdapat dalam di Interactive Book 9\%, menyampaikan pendapat atau jawaban dari pertanyaan $9 \%$, mengajukan pertanyaan $10 \%$, melakukan pengamatan, percobaan, atau bekerja $23 \%$, mendiskusikan masalah $9 \%$, mencatat segala informasi yang didapatkan dari proses pembelajaran $2 \%$, mengerjakan LKS yang ada di di Interactive Book $17 \%$, dan perilaku yang tidak relevan sebanyak $1 \%$.

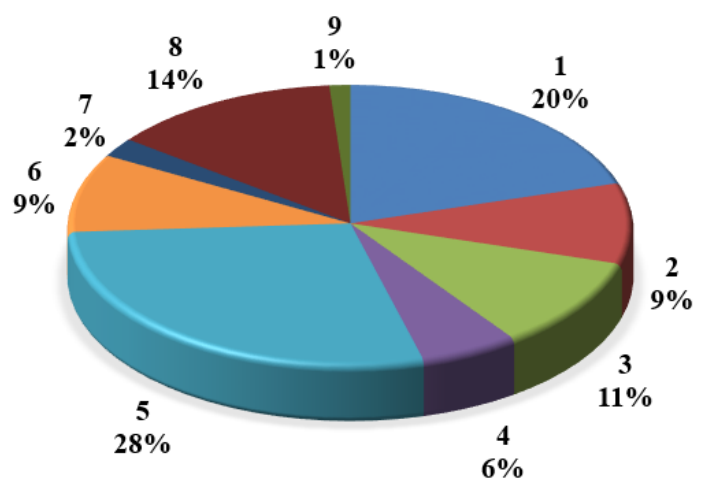

Gambar 3. Persentase Aktivitas Siswa Pertemuan 3

Keterangan:

1. Memperhatikan guru saat memberikan arahan dan informasi

2. Membaca informasi atau bacaan yang terdapat dalam di Interactive Book

3. Menyampaikan pendapat atau jawaban dari pertanyaan yang diajukan oleh guru

4. Mengajukan pertanyaan

5. Melakukan pengamatan, percobaan, atau bekerja

6. Mendiskusikan suatu masalah

7. Mencatat segala informasi yang didapatkan dari proses pembelajaran

8. Mengerjakan LKS yang ada di di Interactive Book

9. Perilaku yang tidak relevan

Gambar 3 merupakan persentase dari aktivitas siswa pada proses pembelajaran pertemuan kedua. Terdapat delapan aktivitas siswa yang diamati 
selama kegiatan pembelajaran berlangsung, diantaranya adakah memperhatikan guru saat memberikan arahan dan informasi sebanyak $20 \%$, membaca informasi atau bacaan yang terdapat dalam di Interactive Book 9\%, menyampaikan pendapat atau jawaban dari pertanyaan yang diajukan oleh guru $11 \%$, mengajukan pertanyaan sebanyak $6 \%$, melakukan pengamatan, percobaan, atau bekerja sebanyak $28 \%$, mendiskusikan suatu masalah 9\%, mencatat segala informasi yang didapatkan dari proses pembelajaran $2 \%$, mengerjakan LKS yang ada di di Interactive Book $14 \%$, dan perilaku yang tidak relevan sebanyak $1 \%$.

Dari tiga pertemuan di atas dapat dirata-rata untuk mengetahui kecenderungan pembelajaran secara keseluruhan.

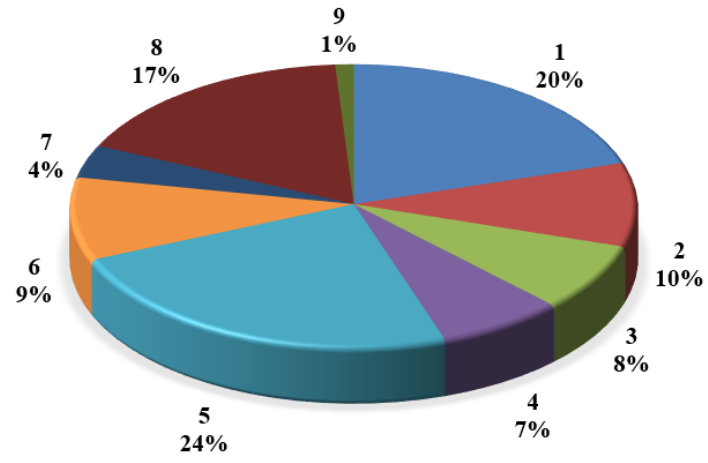

Gambar 4. Rekap Persentase Aktivitas Siswa

Keterangan:

1. Memperhatikan guru saat memberikan arahan dan informasi

2. Membaca informasi atau bacaan yang terdapat dalam di Interactive Book

3. Menyampaikan pendapat atau jawaban dari pertanyaan yang diajukan oleh guru

4. Mengajukan pertanyaan

5. Melakukan pengamatan, percobaan, atau bekerja

6. Mendiskusikan suatu masalah

7. Mencatat segala informasi yang didapatkan dari proses pembelajaran

8. Mengerjakan LKS yang ada di di Interactive Book

9. Perilaku yang tidak relevan

Gambar 4 merupakan persentase dari aktivitas siswa pada proses pembelajaran selama tiga hari. Terdapat delapan aktivitas siswa yang diamati selama kegiatan pembelajaran berlangsung.

Gambar 4 tersebut menunjukkan hasil kegiatan memperhatikan guru saat memberikan arahan dan informasi sebanyak $20 \%$, membaca informasi atau bacaan yang terdapat dalam buku ajar $10 \%$, menyampaikan pendapat atau jawaban dari pertanyaan yang diajukan oleh guru $8 \%$, mengajukan pertanyaan sebanyak $7 \%$, melakukan pengamatan, percobaan, atau bekerja sebanyak
$24 \%$, mendiskusikan suatu masalah $9 \%$, mencatat segala informasi yang didapatkan dari proses pembelajaran $4 \%$, mengerjakan LKS yang ada di di Interactive Book $17 \%$, dan perilaku yang tidak relevan sebanyak $1 \%$.

Keefektivan perangkat pembelajaran dilihat dari respon siswa, tes hasil belajar dan kemampuan berpikir kreatif siswa. Keefektivan perangkat dinilai pada saat penelitian yang dilaksanakan pada bulan Maret 2017.

\section{Respon Siswa}

Respon siswa adalah tanggapan dan pendapat siswa mengenai pembelajaran yang telah dilakukan. Respon siswa ditampung menggunakan angket yang diisi setelah pembelajaran selesai dilaksanakan. Adapun respon siswa yang muncul disajikan pada Gambar 5.

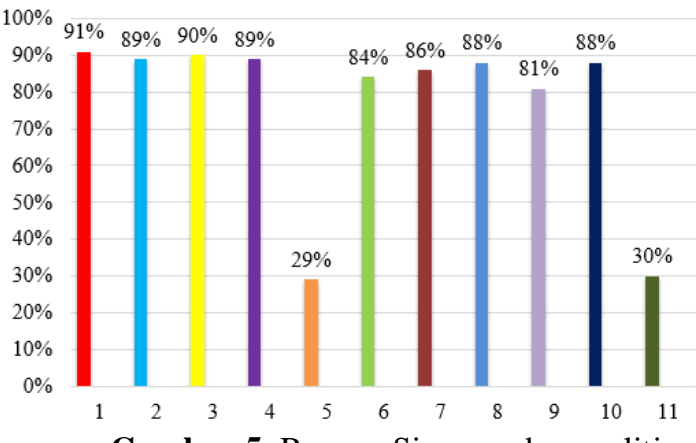

Gambar 5. Respon Siswa pada penelitian

Keterangan:

1. Interactive Book yang dibuat cukup memudahkan dan mendorong saya belajar IPA di sekolah atau di rumah.

2. Saya tertarik pada tampilan buku ajar Interactive Book (gambar dan warna bagus)

3. Saya dapat memahami petunjuk dan arahan yang digunakan dalam buku ajar Interactive Book

4. Saya mudah memahami bahasa dalam buku ajar Interactive Book

5. Saya kesulitan dalam menggunakan interactive book

6. Saya merasa selama pembelajaran suasana kelas menyenangkan

7. Menurut saya cara guru mengajar menyenangkan

8. Saya merasa senang terhadap pembelajaran menggunakan buku ajar Interactive Book

9. Saya selalu terlibat aktif dalam pembelajaran

10. Saya menemukan ide kreatif ketika menggunakan Interactive Book

11. Saya kurang berminat untuk mengikuti pembelajaran dengan menggunakan buku ajar Interactive Book 
Data pada Gambar 5 di atas menunjukkan bahwa siswa pada penelitian ini memberikan respon positif dan tertarik dengan Interactive Book dan komponen-komponen pembelajaran.

\section{Kemampuan Berpikir Kreatif Siswa}

Kemampuan berpikir kreatif siswa dinilai dengan rubrik penilaian yang kemudian disajikan dalam bentuk angka.

\begin{tabular}{ccccccc} 
& \multicolumn{7}{c}{ Tabel 5. Kemampuan Berpikir Kreatif Siswa } & \multirow{2}{*}{ Ketuntasan } & \multirow{2}{*}{ N-Gain } \\
\cline { 2 - 5 } $\begin{array}{c}\text { Aspek Berpikir } \\
\text { Kreatif }\end{array}$ & \multicolumn{3}{c}{ Skor } & \multicolumn{4}{c}{ Pretest } & Postest & Pretest & Postest & \\
\hline Berpikir Asli & 3,55 & 4,08 & $\mathrm{~T}$ & $\mathrm{~T}$ & 0,37 \\
\hline Berpikir Luwes & 3,35 & 4,4 & $\mathrm{~T}$ & $\mathrm{~T}$ & 0,64 \\
\hline Berpikir Rinci & 3,2 & 4,15 & $\mathrm{TT}$ & $\mathrm{T}$ & 0,53 \\
\hline Berpikir Lancar & 3 & 4,25 & $\mathrm{TT}$ & $\mathrm{T}$ & 0,63 \\
\hline Rata-Rata & 3,3 & 4,2 & $\mathrm{TT}$ & $\mathrm{T}$ & 0,55 \\
\hline
\end{tabular}

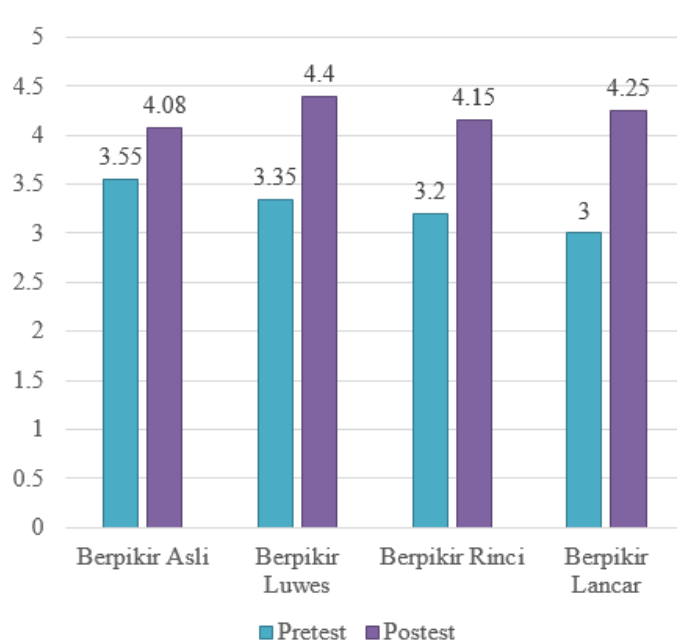

Gambar 6. Kemampuan Berpikir Kreatif Siswa

Berdasarkan Gambar 6 diketahui bahwa pada kemampuan keterampilan berpikir kreatif meningkat dengan $N$-Gain 0,59 (sedang).

\section{Hasil Belajar Siswa}

Hasil belajar siswa dinilai dari tes hasil belajar yang diberikan dua kali yaitu pada saat sebelum dilaksanakan pembelajaran yaitu pretest dan setelah dilaksanakan pembelajaran yaitu posttest.

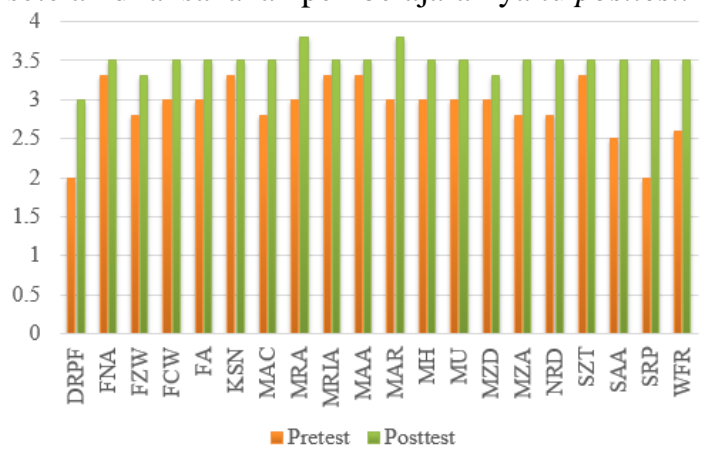

Gambar 7. Ketuntasan dan N-Gain Aspek Pengetahuan Siswa
Berdasarkan Tabel 5 diketahui bahwa pada pretest keterampilan berpikir kreatif sebanyak $43 \%$ siswa tuntas. Posttest keterampilan berpikir kreatif menunjukkan bahwa ketuntasan klasikal mencapai sebesar $100 \%$. ketuntasan dan $\mathrm{N}$-Gain aspek pengetahuan siswa adalah 0,54 (sedang).

Hasil pengembangan buku ajar Interactive Book adalah buku ajar, silabus, RPP, dan tes keterampilan berpikir. Buku ajar yang baik harus memenuhi tiga kriteria yaitu valid, praktis dan efektif.

Berdasarkan uraian yang telah diberikan, Interactive Book dapat meningkatkan hasil belajar siswa. Selain itu buku ajar ini dapat melatihkan keterampilan berpikir kreatif yang dikembangkan secara keseluruhan telah memenuhi seluruh kriteria sebuah perangkat pembelajaran yang baik yaitu memenuhi kriteria kevalidan, kepraktisan dan keefektivan.

Interactive Book untuk melatihkan keterampilan berpikir kreatif sesuai dengan penelitian terdahulu yang dilakukan oleh Marguerite C. Radencich dan Gerry Bohning (1988). Pop Up, Pull Down, Push In, Slide Out Natural Science Action Book. Penelitian ini membuktikan bahwa buku interactive book tidak hanya membantu anak memahami konsep sains tapi juga menambah kesenangan anak untuk belajar dunia alam. Teks dan gambar yang warna-warni serta dapat digerakan membuat buku mudah digunakan, dapat menstimulas, meningkatkan kreativitas, dan memperkaya materi sains.

Penelitian lain dilakukan Benjamin D. Olsen, dkk (2013). Pop-Up Constructions Motivate and Reinforce Science Learning for Upper Elementary Students. Hasil penelitian ini menunjukan bahwa kreativitas anak dapat ditingkatkan melalui penggunaan buku pop up dan pembuatan pop up. Buku ini dapat meningkatkan imajinasi, kemampuan visual, dan berpikir spasial. "They effectively integrated art concepts and creativity with their science work." 
Dari penelitian ini terlihat adanya hubungan antara validasi buku ajar dan perangkat dengan aktivitas guru, aktivitas siswa, serta kreativitas siswa. Validitas Interactive Book dan perangkat oleh ahli yang kemudian digunakan guru dalam pembelajaran dapat mempengaruhi lreativitas siswa. Jal ini sesuai dengan pendapat teori pemodelan oleh Bandura dan Joyce \& Weil (1999) yang mengemukakan lima unsur penting sebagai uraian dari suatu pembelajaran, yaitu (1) sintak, yakni suatu urutan kegiatan yang biasa juga disebut fase, (2) sistem sosial, yakni peranan guru dan siswa serta jenis aturan yang diperlukan dalam pembelajaran, (3) prinsip reaksi, yakni memberi gambaran kepada guru tentang cara memandang atau merespon pertanyaan siswa, (4) sistem pendukung, yakni kondisi yang diperlukan, dan (5) dampak instruksional dan pengiring.

Berdasarkan data pada pembelajaran Interactive Book, aktivitas siswa, dan aktivitas siswa ini siswa dapat mengonstruksi pengetahuan dan meningkatan kreativitas yang dimiliki. Hal ini sesuai dengan jurnal nasional dan internasional serta pendapat teori Konstruktivisme yang didasarkan pada dua teori yang disusun oleh Piaget dan Vygotsky. Piaget meyakini bahwa perkembangan mendahului pembelajaran sedangkan Vigotsky meyakini bahwa pembelajaran mendahului perkembangan (Solso, Maclin, \& Maclin, 2008). Teori kognitif oleh Piaget, perkembangan kognitif manusia pada dasarnya seiring dengan perubahan kemampuan mental manusia dari waktu ke waktu. Perkembangan sebagian besar ditentukan oleh manipulasi dan interaksi aktif anak dengan lingkungan. Untuk menujukan struktur kognitif yang mendasari polapola tingkah laku yang terorganisir Piaget menggunakan istilah skema dan adaptasi. Skema merupakan proses mengorganisasi dan merespon berbagai pengalaman atau skema dapat juga didefinisikan sebagai suatu pola sistematis dari tindakan, perilaku pikiran, dan strategi pemecahan masalah yang memberukan kerangka pemikiran dalam menghadapi berbagai tantangan dan jenis situasi. Adaptasi adalah istilah yang digunakan untuk menunjukan pentingnya pola hubungan individu dengan linkungannya dalam proses perkembangan kognitif.

Dalam grafik aktivitas terlihat aktivitas yang berpusat pada guru sebanyak 20\% dan yang berpusat pada siswa 79\%. Ini menunjukan jika pembelajaran berpusat pada siswa dan guru hanya sebagai pendamping dan fasilitator. Aktivitas yang berpusat pada siswa yang mempengaruhi proses pembelajaran ini sesuai dengan pendapat Vygotsky yang mengatakan bahwa proses belajar akan terjadi efisien dan efektif apabila abak belajar secara kooperatif dengan siswa lain dalam suasana lingkungan yang mendukung, dalam bimbingan, atau pendampingan seorang yang lebih dewasa. Teori lain adalah teori kognitif sosial yang diungkap oleh Bandura. Lingkungan dan peristiwa eksternal dapat mempengaruhi sikap dan suasana hati peserta didik.

Proses berpikir kreatif siswa ketika menggunakan Interactive Book dipicu saat siswa melihat dan mengamati buku ajar ini. Mereka mulai memperhatikan desain, cara kerja, dan penggunaannya. Kemudian diperkuat dengan lembar kerja atau evaluasi yang peneliti sadur dari tes kreativitas Torrance. Evaluasi ini mendorong anak untuk memenuhi empat sintaks berpikir kreatif yaitu berpikir lancar, berpikir luwes, berpikir asli, dan berpikir rinci.

\section{PENUTUP}

Berdasarkan hasil pengembangan buku ajar Interactive Book dan uji coba, maka produk yang dihasilkan pada penelitian ini adalah (1) buku ajar Interactive Book yang dikembangkan peneliti telah divalidasi dan dinyatakan valid dan layak untuk digunakan, (2) buku ajar Interactive Book yang dikembangkan peneliti memiliki tingkat kepraktisan yang tinggi dan dapat digunakan untuk meningkatkan kemampuan berpikir kreatif siswa (3) buku ajar Interactive Book yang dikembangkan peneliti memiliki tingkat keefektifan yang tinggi dan dinyatakan valid untuk meningkatkan kemampuan berpikir kreatif siswa.

Beberapa saran dapat dikemukakan oleh peneliti berdasarkan penelitian yang telah dilakukan adalah sebagai berikut (1) buku ajar Interactive Book Interactive Book materi ekosistem dapat diterapkan dalam pembelajaran untuk meningkatkan keterampilan berpikir kreatif siswa. Hal-hal yang perlu diperhatikan guru dalam penggunaan Interactive Book adalah mempersiapkan dan memahami langkah pembelajaran yang harus dilakukan agar memperoleh hasil yang maksimal, (2) buku ajar ini dapat dikembangkan pada materi lainnya, sehingga dapat menjadi masukan bagi pemerintah untuk meningkatkan kualitas buku ajar yang selama ini beredar, (3) perlu diadakan penelitian lebih lanjut tentang pemakaian Interactive Book dalam pembelajaran di sekolah (4) pada penelitian selanjutnya hendaknya dapat mengembangan Interactive Book dengan berbagai materi yang lain.

\section{DAFTAR PUSTAKA}

Arikunto, Suharsimi. 2010. Prosedur Penelitian Suatu Pendekatan Praktik. Jakarta: Rineka Cipta. 
Badan Standar Nasional Pendidikan. 2006. Standar Isi Kurikulum Tingkat Satuan Pendidikan. Jakarta: Departemen Pendidikan Nasional.

Borich, GD. 1994. Observation Skills for Effective Teaching. New York: Merril Publishing Company.

Olsen, Benjamin D., Ksenia, S. Zhbanova., Parpucu, Harun., Alkouri, Zaid., and Rule, Audrey C. 2013. "Pop-Up Constructions Motivate and Reinforce Science Learning for Upper Elementary Students". Science Activities 50:119 133, 2013. Diakses melalui Routledge.

Republik Indonesia. 2003. Undang-Undang No. 20 Tahun 2003 tentang Sistem Pendidikan Nasional. Sekretaris Negara. Jakarta.

Republik Indonesia. 1997. Undang-Undang No. 23 Tahun 1997.tentang Lingkungan Hidup. Sekretaris Negara: Jakarta.

Sanyoto, Sadjiman.E. 2006. Metode Perancangan Komunikasi Visual Periklanan. Yogyakarta: Dimensi Press
Solso, R.L., Maclin, O.H., \& Maclin, M. K. 2008. Cognitive Psychology. Pearson Education.

Supardi. 2014. Ide-Ide Kreatif Mendidik Anak bagi Orang Tua Sibuk. Yogyakarta: Ar-Ruzz Media 2014.

Thiagarajan, Sivasailam., Semmel, Dorohy.S., dan Semmel, Dorothy.S., dan Semmel. Melvyn.I. 1974. Instructional Development for Training Teachers of Exceptional Children A Source Book. Minneapolis, Minnesota: Leadership Training Institute/Special Education, University of Minnesota.

Torrance, E. Paul. 1976. Guiding Creative Talent. New York: Robert E. Kreiger.

Widiyoko, S. Dan Putra, Eko. 2012. Teknik Penyusunn Instrumen Penelitian. Yogyakarta: Pustaka Pelajar. 